\section{METAPHYSICAL NECESSITY \\ IN THE NEO-SADRAIAN \\ SCHOOL AND ASSESSMENT \\ OF NECESSITARIAN \\ THEORIES OF THE LAWS OF NATURE}

Abstract: To differentiate between the laws of nature and accidental generalizations, we must adopt a view of necessity that is capable of being realized in relationships existing among natural objects. In neoSadraian Islamic philosophy, metaphysical necessity is accepted as part of the cause-effect relationship. This paper compares the neo-Sadraian interpretation of necessity and necessitarian theories about the laws of nature, particularly essentialism and universal theory. By resorting to specific forms al-shûrat al-naw'iyyah, the origin of the essential properties of natural objects, I argue that neoSadraians have proposed a perspective on metaphysical necessity that is epistemologically a posteriori.

Keywords: metaphysical necessity; a posteriori; neo-Sadraian;

essentialism; universal theory; laws of nature

\section{Metafyzická nutnost v neosadrijské škole a hodnocení nezbytných teorií přírodních zákonů}

Abstrakt: Abychom mohli rozlišit mezi prírodními zákony a náhodnými zobecněnimi, je třeba chápat nutnost jako vztah, který může platit mezi přirozenými objekty. $V$ neo-sadraianské islámské filosofii je metafyzická nutnost chápána jako součást vztahu príčiny a následku. Tento článek srovnává neo-sadraianské pojetí nutnosti s teoriemi nutnosti prírodních zákonů, zejména $s$ esencialismem a univerzální teorií. $S$ prìlédnutím ke konkrétním formám al-shûrat al-naw'iyyah, tedy $k$ původu základních vlastností prírozených objektů, se pokusím ukázat, že neo-sadraianští filosofové navrhli perspektivu metafyzické nutnosti, která je epistemologicky a posteriori.

Klíčová slova: metafyzická nutnost; a posteriori; Neo-Sadraian; esencialismus; univerzální teorie; zákony prírody

\section{JAVAD DARVISH AGHAJANI}

Depart. of the Philosophy of Science Sharif University of Technology Azadi Ave, Tehran, Iran

PO Box: 11365-11155 email / javad.darvish@gmail.com (iD) 0000-0003-0915-4471

\footnotetext{
(c) (1) This work is licenced under the Creative Commons Attribution 4.0 International License.
} 


\section{Introduction}

Generally speaking, there are two perspectives about modality, the precise concept of necessity, in contemporary analytic philosophy. In the first perspective, based on the concepts of David Hume, necessity is reduced to the properties of propositions which are epistemologically a priori and logically true. ${ }^{1}$ This approach admits of necessity in logic but rejects it in metaphysics. This view has been embraced by contemporary naturalist metaphysicians who are skeptical about modal concepts in metaphysics. ${ }^{2}$

The second perspective incorporates a more robust notion of necessity, and modality in general, into its metaphysics. Saul Kripke, known for having revived the idea of necessity in contemporary metaphysics, demonstrated that there is a type of metaphysical necessity that is epistemologically a posteriori. According to this interpretation, necessity is objectively realized and is not limited to the logical properties of propositions. Each of these metaphysical approaches has become a philosophical foundation for divergent theories about the laws of nature. The necessitarian views presented herein refer specifically to the two theories. i.e., universals and essentialism. The former considers the necessary relationship between the universals and believes that physical necessity exists in the actualized world. The latter holds that necessity is rooted in the essential properties of natural objects and, because these properties exist in every possible world, it is a metaphysical necessity.

Although neo-Sadraians in Islamic philosophical tradition have not entered into the discourse on the purported laws of nature, they have advocated the notion of causal necessity. They attribute the origin of such necessity in nature to the essence of the natural object. By explaining the neo-Sadraian philosophical perspective, the present article seeks to investigate the relationship between the concept of necessity as developed in this philosophical school and the necessitarian theories of the laws of nature developed in contemporary analytic philosophy.

Neo-Sadraian philosophy allows us to define necessity in nature using the concept of the "specific form" (al-shûrat al-naw'iyyah) of a natural object which makes up its essential properties. This approach corresponds to an interpretation of essentialism about laws which attributes necessity to the

\footnotetext{
${ }^{1}$ See David Hume, A Treatise of Human Nature (Waiheke Island: The Floating Press, 2009), 131-34.

${ }^{2}$ See Michael J. Loux and Thomas M. Crisp, Metaphysics: A Contemporary Introduction (New York: Routledge, 2017), 150.
} 
dispositional properties of a natural object. This is ontologically opposed to the theory of universals but, from an epistemological perspective, it agrees with the other two perspectives in considering necessity to be a posteriori.

In the present article, by neo-Sadraians are meant those philosophers in the Islamic tradition who have adopted the general principles of Sadra's transcendent philosophy and have contributed to and complimented his school or, in some cases, endeavored to reinterpret his transcendent philosophy in light of modern philosophical and scientific theories. These philosophers include Molla Hadi Sabzavari (1797-1893), Muhammad Husayn Tabatabaei (1903-1981), Morteza Motahari (1920-1979), Mehdi Ha'eri Yazdi (1923-1999), and Mohammad-Taqi Mesbah Yazdi (1934-2021).

Although a variety of definitions have been proposed for the laws of nature, they all arguably have the following five elements in common: ${ }^{3}$

- Propositions expressing the laws of nature have the characteristic of factual, not logical, truth.

- The truth of propositions expressing the laws of nature is not dependent on a specific time or place.

- Propositions expressing the laws of nature do not contain proper names.

- Propositions expressing the laws of nature are universal, statistical claims and are presented in general terms.

- Propositions expressing the laws of nature are conditional claims.

Different perspectives have been propounded about the laws of nature. In this regard, the first question is whether or not anything can rightly be called a law of nature independent of knowing the subjects. Some have responded negatively ${ }^{4}$ to this question. Among those who provide a positive response, some argue that the laws are necessary and others believe that they are not necessary. ${ }^{5}$ Among the philosophers who believe in the necessity of the laws, some consider this necessity to be physical and others regard it to be metaphysical. The present article examines the last two items, namely, necessitarian theories.

\footnotetext{
${ }^{3}$ See Norman Swartz, "Laws of Nature," in Internet Encyclopedia of Philosophy, accessed February 19, 2021, http://www.iep.utm.edu/lawofnat.

${ }^{4}$ As do anti-realists, see, e.g., Bas C. van Fraassen, Laws and Symmetry (Oxford: Oxford University Press, 1989), 181.

${ }^{5}$ Such as David Lewis, "New Work for a Theory of Universals," Australasian Journal of Philosophy 61, no. 4 (1983): 366.
} 
The first part of this article discusses the neo-Sadraian perspective on necessity. In this section, necessity in neo-Sadraian philosophy will be initially examined from an ontological perspective. Then, focusing on the relationships found in nature, the notion of the origin of necessity in natural relationships will be explained and it will be determined if they are known a priori or a posteriori. The second part sets out to clarify universal and essentialist accounts of the laws of nature. In the last part, these three perspectives will be compared in terms of the ontology and epistemology of necessity as well as with regard to their reflections on the state of law.

\section{Neo-Sadraian Islamic Philosophy and Necessity}

In this section, I seek to determine whether the neo-Sadraian view of necessity is similar to that of any of the analytic philosophers. I initially ask whether or not neo-Sadraian philosophers consider necessity to be merely subjective issue or if it also is realized to be objective. The second subsection discusses how - if necessity is, in fact, objectively realized - one is able to gain epistemic access to it.

\subsection{Ontological Explanation of Necessity}

Tabatabaei distinguished four types of necessity: ${ }^{6}$

1. Pre-eternal necessity: where the predicate is essentially and unconditionally necessary for the subject. An example of this necessity is the existence of God.

2. Essential necessity: where the predicate is inherently necessary for the subject, but provides the condition of existence of the subject. An example is the proposition "Man is an animal."

3. Descriptive necessity: where the predicate is necessary for the subject because it is an attribute of the subject. An example is the movement of the hand for a writer.

\footnotetext{
${ }^{6}$ See Sayyed Muhammad Husayn Tabatabai, Nihayat Al-Hikmah (Qom: Muassasah al-Nashr al-Islamiyah, 1984), 46. It should be noted that above categorization is rooted in Avicenna's philosophy. Avicenna categorized necessity into six types: (1) pre-eternity necessity (which is unconditional); (2) necessity with a predicate condition; (3) essential necessity (absolute); (4) a general condition (equivalent to the descriptive necessity of Tabatabaei); (5) absolute over time; (6) absolute distribution (the same as absolute over time, but where time is indefinite). See Avicenna, Kitab Al-Najat [The Book of Deliverance] (Tehran: University of Tehran, 2001), $35-40$.
} 
4. Necessity due to time: similar to descriptive necessity, yet limited to a specific time.

When critiquing Tabatabaei, Motahari categorized the approaches to necessity in a different way. Tabatabaei's categories, he argues, belong to the discipline of logic and can be applied to the propositions regardless of the discipline to which the predicate and subject belong. While a logician is concerned with entirely subjective issues, a philosopher is concerned with the external reality of being; therefore, the issue of necessity must refer to external reality, rather than merely subjective form. ${ }^{7}$

Islamic philosophy distinguishes between two types of necessity: ${ }^{8}$ essential philosophical necessity (bi-l-dhät) and necessity by something else (bi-l-ghayr). ${ }^{9}$ Essential philosophical necessity refers to a sort of existential necessity that is caused by the essence of the object without the involvement of other objects. Necessity by something else is the necessity that pertains to an object stemming from an external cause. Put simply, essential philosophical necessity means that the object's existence is self-sufficient and independent, while necessity by something else means that its existence is affected by and dependent upon another object.

This distinction is pertinent to the dialogue between neo-Sadraian and contemporary analytic philosophy. Here, as well as in the metaphysics of David Hume, being based in logical relations, essential necessity and descriptive necessity are epistemologically a priori and semantically analytic. However, in the realm of philosophy, essential philosophical necessity and necessity by something else, both of which refer to external reality, are objectively recognizable. According to the interpretation of philosophers, the main reason for this claim is that necessity is rooted in the causal relationship. Furthermore, the causal connection in Sadraian philosophy is based

\footnotetext{
${ }^{7}$ See Morteza Motahari, Majmue Asar-e Ostad Motahari [The Collected Works of Motahari] (Tehran: Sadra, 2005), vol. 10, 98.

${ }^{8}$ See Morteza Motahari, Majmue Asar-e Ostad Motahari [The Collected Works of Motahari] (Tehran: Sadra, 2005), vol. 6, 557-60.

${ }^{9}$ Tabatabai and most neo-Sadraian philosophers add to these two types relative necessity (the same as necessity with a predicate condition in Avicenna), which means that when an object is compared to another object, it is necessary for it to include that object. See Sayyed Muhammad Husayn Tabatabai, Bidayat Al-Hikmah (Qom: Muassasah al-Nashr al-Islamiyah, 1995), 45. Ha'eri Yazdi considers this kind of necessity as equivalent to tautological propositions. See Mehdi Ha'eri yazdi, Heram e Hasti [Pyramid of the Universe] (Tehran: Institute of Cultural Studies and Research, 1982), 45.
} 
on the principle of primacy of existence. These two propositions will be explained below.

Overall, in Islamic philosophy, the causal relationship is existential; that is, one side of the relationship confers existence and the other side comes into existence. Most Muslim philosophers (including neo-Sadraian philosophers) have affirmed the philosophical rule of the impossibility of separation of the effect from the complete cause because of this relationship between cause and effect. This rule demonstrates the necessary connection between cause and effect and different schools of Islamic philosophy have proposed different reasons for this necessary relationship. ${ }^{10}$

Emphasizing the principle of the primacy of existence, ${ }^{11}$ and the principle of gradation of existence, ${ }^{12}$ Sadra argued that the quality of existence of a contingent being is the criterion for the need for a cause. In Sadra's view, the existence of the effect is not completely different from the existence of

${ }^{10}$ The main dispute among Islamic philosophers concerns the criteria for the need of an effect for a cause. Avicenna, as well as philosophers advocating the primacy of quiddity, argue that the criterion for this need is the contingency of quiddity and the contingent nature of the effect. This means that anything which is not necessary, and for which the assumption of nonexistence does not lead to contradiction, needs a cause to exist. See Avicenna, The Metaphysics of The Healing (Brigham: Brigham Young University Press, 2005), 213-15.

${ }^{11}$ In summary, this principle states that if we observe objects in the external world, two things are distinguishable: first, the existence of an object, and second, its quiddity. Existence, here, could be used to provide a simple answer to the question "is there anything?" In this regard, it does not matter what that thing is. For example, when we ask about something which is located very far away, we are not concerned with its details. Rather, we want to know if there is anything instead of nothing. On the other hand, quiddity, means the nature of things and could be used as an answer to the question of "what is it?" Here, the questioner knows that there is something but wants to know more about its details. Accordingly, the primacy of existence states that what is ontologically more fundamental is existence, not quiddity. Moreover, what exists as a consequence of existence and is derivative is the quiddity. In the sense in which Tabatabaei believes and calls the "unity of being", basically there is nothing in the world but "existence" and all the things that exist are ranks and degrees of a simple, single existence. See Tabatabai, Nihayat Al-Hikmah, 9-11.

${ }^{12}$ The principle of the gradation of existence expresses that existence comes in various degrees. Therefore, it has been likened to light: existence, like light, is one reality which is actualized with differing strengths and weaknesses. Thus, existence is unitary, because it is one reality which actualizes in the external world and, simultaneously, it is multitudinal, because it possesses different degrees (ibid., 17-18). Kalin, a contemporary Muslim philosopher, named this view "gradational ontology." He stated that: "Sadra construct a hierarchical view of existence whereby things are defined in proportion to their 'ontological intensity' or lack thereof. Since equivocality implies different degrees and grades of existence, I shall call this "gradational ontology." See Ibrahim Kalin, Knowledge in Later Islamic Philosophy: Sadra on Existence, Intellect, and Intuition (Oxford: Oxford University Press, 2010), 101-2. 
the cause. However, what separates the effect from the cause is that effect occupies a lower level than cause in the hierarchy of existence; thus, effect has an essential need to cause, as well as a continuous dependence on the cause ${ }^{13}$ Here, existence is divided into the independent and the copulative. Copulative existence refers to effects that cannot exist independently of the cause, but whose entire existence is dependent on the cause. Therefore, Sadra and the neo-Sadraians introduce the concept of ontological indigence to explain the continual attachment of the effect to the cause and their essential relationship. In this explanation, the existence of the effect is nothing but dependent on the cause, and it is impossible to assume their separation. Thus, the existence of the cause necessitates the existence of the effect.

Hence, to return to the initial question, I should note that necessity in Neo-Sadraian philosophy is not limited to logical necessity. Instead, because the relationship between cause and effect is an existential and external relationship, necessity, which is a vital component of this relationship, is objective and external. Therefore, it is not reducible to logical (essential or descriptive) necessity. In summary, then, the following points can be made:

1. Neo-Sadraian philosophy has two types of necessity: logical necessity, which concerns mental and analytical issues, and philosophical necessity, which involves existence and external reality.

2. Philosophical necessity is derived from the cause-and-effect relationship (the philosophical rule of the impossibility of separation of the effect from the complete cause).

3. The relationship between the cause and the effect is existential. Moreover, the criterion for the need for a cause in neo-Sadraian philosophy is ontological indigence, which is rooted in the fact that effect occupies a lower level than cause in the hierarchy of existence (the principle of causality and ontological indigence).

4. Existence is not only externally realized, but also, in the external world, nothing but existence is actualized (primacy of existence).

Consequently, necessity in neo-Sadraian philosophy is externally realized and is not merely a mental description. To determine whether this necessity is epistemologically a priori or a posteriori requires focusing on nature itself and explaining the neo-Sadraian approach regarding relationships in nature. This is the topic of the next section.

${ }^{13}$ See Mohammad Ibn Ibrahim Sadr al-Din al-Shirazi, Al-Hikma Al-Mutáaliya Fi-l-Asfar Al'aqliyya Al-Arba'a (Beirut: Dar ehya al-torath al-arabi, 1981), vol. 2, 299-301. 


\subsection{Necessity in Nature: An Epistemological Analysis}

Our discussion thus far has ranged over anything existent, whether material or immaterial. For the purpose of this article, I will from now on confine our discussion to the natural world. There is no such thing as the laws of nature in Islamic philosophy; nevertheless, the character of relationships among natural phenomena may be inferred from the discussions of the material world.

What characterizes the material world and distinguishes it from the other worlds $\mathrm{s}^{14}$ is eternal change and permanent motion. According to Sadra and his followers, change is the most essential and fundamental feature of the natural world. Indeed, nature is nothing but change and change is in the essence of matter, rather than being something that affects it from the outside..$^{15}$ This is the concept of substantial motion and is recognized as one of Sadra's most significant contributions to Islamic philosophy. Motion is defined as transforming continually from the mode of the potentiality to the mode of the actuality of matter. ${ }^{16}$ In Sadraian philosophy, one of the divisions of existence is that of the potential versus the actual. In the external world, however, there is only equivocal, graded existence that is sometimes in the potential and sometimes in the actual mode. ${ }^{17}$ For example, water has the capacity to turn into steam; thus, water and steam are the same being which can exist in different modes.

It appears that the key to discussing the laws of nature in Islamic Philosophy is the analysis of the relationship between potentiality and actuality. As mentioned, potentiality and actuality are two modes of the spectrum of existence that are distinguished by the intensity and weakness of their existence. Returning to the principle of gradation of existence, it could be said that the relationship between potentiality and actuality in neo-Sadraian philoso-

\footnotetext{
${ }^{14}$ Following Sadra, neo-Sadraians argue that the world of existence consists of three levels: First, the world of intellect, which is the world of abstractions and is completely devoid of matter and material effects. Second, the imaginal world, which is devoid of material substance but consists of material manifestations such as shape or dimensions. And third, the material world, which is at the lowest level in the hierarchy of the universe (see Tabatabai, Bidayat Al$H i k m a h, 142)$ and can be considered as parallel to nature.

${ }^{15}$ See Mohammad Ibn Ibrahim Sadr al-Din al-Shirazi, Al-Hikma Al-Muta'aliya Fi-l-Asfar Al'aqliyya Al-Arba'a (Beirut: Dar ehya al-torath al-arabi, 1981), vol. 3, 39-40.

${ }_{16}$ Aristotle, Physics (New Brunswick: Rutgers University Press, 1995), 201a, 10, 11.

${ }^{17}$ See Tabatabai, Nihayat Al-Hikmah, 196-98.
} 
phy is a continuous and fluid one and that this fluidity is due to substantial motion. As Motahari puts it: ${ }^{18}$

Contrary to the views of Aristotle and Avicenna and their followers, the transformation of possibility (potentiality) into actuality does not include two types, namely, immediate and gradual, but rather is solely gradual and in the form of motion..$^{19}$

This kind of relationship shows that, in nature, there is an existential, connective relationship between beings that transform into one another, such as an acorn that turns into an oak or an ovum that turns into a human being. This means that the two items in each such pairings are not separate beings. As Tabatabaei argues, potentiality and actuality are the same existence, and there is no distance between them. However, this lack of distance does not indicate that potentiality and actuality have the same physical form (al-shûrat al-jismiyyah) but rather refers to their unity in a specific form (alshûrat al-naw'iyyah), the form that is the source of the specific characteristics and properties of an object. In other words, the tree-ness of a tree and the human-ness of a human are due to differences in their specific forms. ${ }^{20}$

Moreover, the unity of an ovum and a human and the fact that they are the same existence is due to the unity of their specific forms, and their difference is due to the difference in their physical forms. ${ }^{21}$ The specific form, in this view, is the efficient cause of the physical forms. As seen previously, there is an objective, necessary, and existential relationship between the cause and the effect. The same necessity implies that the apple seed must necessarily become an apple tree (and not an apricot tree) if it is not impeded.

${ }^{18}$ See Motahari, Majmue Asar-e Ostad Motahari [The Collected Works of Motahari], vol. 6, 757.

${ }^{19}$ As a simple and non-composite thing, how existence accepts gradual change at the same time remains unit is a problem for some philosophers. The problem is that gradual motion requires that the various components and parts of an object be realized at a distance from each other, so that, first one element comes and then the other. But this kind of motion disrupts unity. Mehdi Ha'eri Yazdi, answers this objection by stating that the natural object in the external world is distinguishable in two ways; first in terms of continuous unity and second in terms of multiplicity of moments. According to continuous unity, motion is indivisible, and the simplicity of movement is in terms of its continuous unity. This continuous unity preserves the unity of motion during gradual changes. See Mehdi Ha'eri yazdi, Sharh $-i$ Harakat-i Asfär [Explanation of Motin in Asfar] (Tehran: Hekmat, 2015), 40.

${ }^{20}$ See Tabatabai, Nihayat Al-Hikmah, 106.

${ }^{21}$ Ibid., 108. 
Nevertheless, the critical point is that this necessity cannot be a priori. Instead, understanding this necessity requires knowledge of the essence, which is a set of essential properties, and the essential properties of natural objects are known by grasping the specific form, which is obtained a posteriori. Tabatabai's argument showing that the epistemic access to the specific form should be a posteriori can be reconstructed as follows: when we observe various objects and analyze them empirically, we find differences among them. These differences are due to the origin of the specific effects of each object, which is called the specific form. Therefore, without empirical examination, we cannot trace the real effects and the origin of these real effects. ${ }^{22}$ Elsewhere, Tabatabai acknowledges that, because we may consider some of the non-essential properties of an object to be essential ones, we must employ scientific theories in order to understand the real, inherent, and essential properties of objects. ${ }^{23}$ In summary, it can be said that:

1. In neo-Sadraian philosophy, nature refers to the material world, having the characteristic of motion.

2. Change and motion are the results of an object reaching actuality from potentiality.

3. Potentiality and actuality are not independent beings, but rather two stages of the same fluid being (the principle of gradation of existence).

4. The unity of potentiality and actuality is due to their specific form and their difference is due to their physical form.

5. The specific form is not only the origin of the essential properties of the object, but also the efficient cause of the substantial physical properties. ${ }^{24}$

6. The relationship between cause and effect is necessary.

7. The necessity between the causal relationship of the specific form and the substantial physical properties implies the necessity of the relationship between potentiality and actuality.

\footnotetext{
${ }^{22}$ See Tabatabai, Nihayat Al-Hikmah, 107.

${ }^{23}$ See Motahari, Majmue Asar-e Ostad Motahari [The Collected Works of Motahari], vol. 6, 870.

${ }^{24} \mathrm{Neo}-$ Sadraians, as well as neo-Aristotelians, distinguish between accidental properties and substantial properties. Accordingly, substantial properties are intrinsic and lead to the natural tendency toward a particular formation, such as the tendency of the acorn to become an oak tree. Accidental properties are those that are extrinsic or imposed from the outside, such as the rotting of acorns (instead of becoming a tree). Feser illustrates this point properly in Edward Feser, "From Aristotle to John Searle and Back Again: Formal Causes, Teleology, and Computation in Nature," Nova et Vetera 14, no. 2 (2016): 460-62.
} 
8. The specific form can be known a posteriori and through observation of the substantial physical properties of the objects.

The result is that the relationship between potentiality and actuality, which is truly the relationship between the essentials (or dispositional properties) of an object and their specific manifestations (substantial physical properties), is a necessary objective relationship that is identifiable a posteriori.

\section{Necessitarian Perspectives on the Laws of Nature}

One of the significant questions with respect to the laws of nature is which criterion distinguishes between accidental generalizations and the laws of nature. David Armstrong illustrates the role of this criterion by asking us to consider the following propositions: ${ }^{25}$

- All gold $(\mathrm{Au})$ spheres are less than 1 mile in diameter.

- All enriched uranium (U235) spheres are less than 1 mile in diameter.

Both of these propositions have the three properties of truth, possibility, and universality. Still, the former is not a law of nature, merely an accidental regularity. In contrast, the critical mass of uranium prevents the formation of a uranium sphere that is 1 mile in diameter; thus, this is physically impossible. Therefore, the first proposition is merely a generalization, while the second one has been deduced from the existing causal order in nature, and is a law of nature.

Analytic philosophers argue that the criterion for recognizing this difference is the property of supporting counterfactuals. ${ }^{26}$ While a law of nature guarantees the truth of a counterfactual, accidental generalizations do not play such a role. Armstrong's first proposition cannot be written as a true counterfactual, whereas the second proposition can. However, the feature of a law that guarantees the truth of a counterfactual is, in fact, necessity. When I say, "If it had rained, the ground would have been wet," what makes this counterfactual true is the necessary law that governs the relationship

\footnotetext{
${ }^{25}$ See David Armstrong, What Is a Law of Nature? (Cambridge: Cambridge University Press, 1983), 17-18.

${ }^{26}$ Counterfactuals are conditional statements in which the statement in the indicative corresponding to the antecedent is not true or, in fact, has not been realized, such as "if ' $a$ ' had occurred, then 'b' would also have occurred".
} 
between the falling of rain and wetness of the ground. What the necessitarian perspectives on the laws of nature have to say about the nature and origin of necessity will be explained in this section.

\subsection{Contingent Necessity and the Theory of Universals}

The primary motivation behind the development of the theory of universals was to reconcile two opposing views in the philosophy of science and analytic metaphysics. ${ }^{27}$ These two views are the embracing of necessity as a prerequisite of counterfactuals, on the one hand, and the exclusion of necessity from metaphysics as an implication of naturalism, on the other.

As a naturalist analytic philosopher, David Armstrong accepts the naturalistic requirement to deny abstract entities such as sets and numbers. In this sense, it is generally said that most naturalists are nominalists; however, although he rejects nominalism, Armstrong tries to present an interpretation of universals ${ }^{28}$ which is realistic about universals while not violating naturalism..$^{29}$ By accepting the principle of instantiation, ${ }^{30}$ he takes only those universals to be real that have an instance(s) in the physical world. He thus preserves the linkage between universals and nature.

Armstrong defines laws as the necessary relations between the universals. ${ }^{31}$ This means that, if there is a universal $F$ and a universal $G$, and a relationship $N$ that makes $F$ necessary for $G$ (that is, if something is an instance of $F$, then it is also an instance of $G$ ), then $N$ is a law. This relation is illustrated as follows: ${ }^{32}$

$$
N(F, G) \leftrightarrow \forall x(F x \rightarrow G x)
$$

${ }^{27}$ In the 1970s, Dretske, Tooley, and Armstrong independently proposed almost identical perspectives on the laws of nature, now known as the theory of universals or the Platonic perspective on the laws of nature. This paper primarily refers to Armstrong's ideas in order to explain this perspective.

${ }^{28}$ The term universal, which is contrary to a particular, refers to common properties of some particular that the mind abstracts and gives a single name to. Universals themselves do not have objective, external realizations, but a universal can be instantiated in several real object (see Loux and Crisp, Metaphysics, 17), such as the universal "human" for which the various humans in the world would be instances.

${ }^{29}$ See Armstrong, What Is a Law of Nature?, 75-76.

${ }^{30}$ This principle states that for each universal, there is one or more particular in the physical world that is an instance of that universal.

${ }^{31}$ See David Armstrong, "Laws of Nature As Relations Between Universals, and As Universals," Philosophical Topics 13, no. 1 (1982): 8.

${ }^{32}$ Ibid., 12. 
If, for example, $F$ is the property of being copper and $G$ is the property of being a conductor of electricity, according to $N$, any metal that is copper is also a conductor of electricity. However, a few points should be considered about $N$ and laws within the context of the theory of universals.

Firstly, $N$ itself is universal. Universals are of two types: properties such as greenness and relational such as fatherhood. ${ }^{33}$ Relational universals are divided into several categories, one of which is the relation of necessitation, according to which $N$ is a kind of second-order universal that necessitates relations between the first-order universals. Thus, if $N$ is a universal, and universals, as Armstrong argues, all have at least one physical instance, then $N$ cannot explain some of the scientific laws, (such as Newton's First Law) which do not have an instance in the physical world.

Secondly, as mentioned, Armstrong seeks to remain committed to metaphysical naturalism. According to metaphysical naturalism, only those things that have been obtained from natural sciences have real existence. ${ }^{34}$ Therefore, because $N$ is only found in the actual physical world, not in any possible world, it is said that $N$ represents physical (or natural or contingent) necessitation.

Thirdly, if $N$ is physically necessary, it is only knowable a posteriori and through natural science. We might, then, imagine David Hume asking Armstrong: "Where can one detect a necessary relation in the actual physical world?" and "How is this necessity identifiable through the scientific method?"

This is indeed the Achilles' heel of Armstrong's theory. Armstrong responds that, in nature, we only see regularities; nevertheless, the best explanation for these regularities is the existence of necessary laws. Therefore, Armstrong's way of obtaining knowledge of necessary laws is the inference to the best explanation (IBE). ${ }^{35}$ Tooley also argues that $N$ should be considered a theoretical term that is presumed in order to explain the relation between $F$ and $G \cdot{ }^{36}$ In fact, Tooley takes the reference to "law" to explain the relations between universals based on it. This means that in order to obtain a "law," he has turned to explanation, whereas in philosophy, the appeal to "law" is

\footnotetext{
${ }^{33}$ Depending on their level of abstraction, universals may be first, second, or third-order. For example, redness is a first-order universal while having color is a second-order universal. ${ }^{34}$ See Jaegwon Kim, "The American Origins of Philosophical Naturalism," Journal of Philosophical Research 28 (2003): 90.

${ }^{35}$ See Armstrong, What Is a Law of Nature?, 51.

${ }^{36}$ See Michael Tooley, "The Nature of Laws," Canadian Journal of Philosophy 7, no. 4 (1977): 673-74.
} 
always made for the purpose of explanation..$^{37}$ In fact, explanatory power is what is conferred by laws, such as in the deductive-nomological (DN) model of explanation.

\subsection{Metaphysical Necessity and Theory of Essentialism}

The theory of essentialism ${ }^{38}$ begins with a critique of the inability of the theory of universals to explain the identity of laws and the origin of necessity (the Achilles' heel of Armstrong's theory, as noted above). Essentialists believe that the theory of universals does succeed in distinguishing between accidental generalizations and the laws of nature, yet leaves the identity and origin of laws unclear. ${ }^{39}$ In addition, Armstrong's emphasis on the contingency of the laws of nature to maintain his naturalistic metaphysics in practice brings him closer to Hume's perspective. ${ }^{40}$ Hume defines law as the observed order of actualized natural objects, meaning that law is independent of natural objects; rather, it is an external thing governing natural phenomena. ${ }^{41}$

Essentialists define the laws of nature based on the necessitation relation, which supervened upon the essence of natural objects. This definition can both solve the problem of the identity of laws because it specifies the origination of laws, and also provide an answer to the problem of necessitation. Thus, the essentialist perspective is based on the following principles:

1. The fundamental properties of natural kinds are essentially dispositional (in contrast to Hume's opinion that considers their fundamental properties to be categorical).

2. The relations between natural kinds that are rooted in their dispositional properties are necessary.

a. This indicates that natural kinds may be defined according to their dispositional or categorical properties. Categorical properties

\footnotetext{
${ }^{37}$ See Alexander Bird, "The Dispositionalist Conception of Laws," Foundations of Science 10 (2005): 356.

${ }^{38}$ This perspective is based on Aristotelian metaphysics and developed under the essentialist project that Kripke and Putnam revived in contemporary analytic philosophy. Recently, Alexander Bird and Brian Ellis have extended this approach to the laws of nature.

${ }^{39}$ See Bird, "Dispositionalist Conception of Laws," 356-57.

${ }^{40}$ See Alexander Bird, Nature's Metaphysics: Laws and Properties (Oxford: Clarendon Press, 2007), 3-4.

${ }^{41}$ See Brian Ellis, The Philosophy of Nature: A Guide to the New Essentialism (Stocksfield: Acumen Publishing Limited, 2002), 70-72.
} 
are fixed, actualized, and passive, while dispositional properties are potential and active. ${ }^{42}$ Essentialists argue that the fundamental properties of a natural kind that indicate its essence are its dispositional properties. ${ }^{43}$ For example, the solubility of salt in water is a dispositional property of salt. The point here is that the essence of salt depends on these properties, not actual properties such as solidity and saltiness.

b. This acknowledges that the relations between natural kinds are determined by the manifestations of their dispositional properties under different conditions. Additionally, the law of nature supervenes upon these relations. Because this law is based on essential and dispositional properties, it applies to all possible worlds; therefore, these relations are metaphysically necessary. In the example of water and salt, being soluble for salt and being a solvent for water are both metaphysically necessary because these features are rooted in their essences. This is unlike categorical properties such as color and shape that are not metaphysically necessary for salt and water because they change in different physical states (or possible worlds). Bird illustrates this relation as follows: ${ }^{4}$

$$
\begin{aligned}
& D x \leftrightarrow S x \square \rightarrow M x^{45} \\
& (D x \& S x) \rightarrow M x
\end{aligned}
$$

This relation is called conditional analysis (CA) and the law supervenes upon it. CA indicates that object $x$ has dispositional property $D$ if and only if, when stimulus property $S$ affects it, it demonstrates manifestation property $M$. For example, an object that has elasticity tends to stretch under pressure or tension without deformation. According to the above relationship, $D$ would be the elastic property of the object, $S$ would be the compression or tension, and $M$ the elongation without deformation. An important point to note here is that, because dispositionalism involves the essence of objects, then the CA relationship defines the nature of $D$ rather than just analyzing its conception. ${ }^{46}$

\footnotetext{
${ }^{42}$ See Bird, Nature's Metaphysics, 44.

${ }^{43}$ Ibid., 24.

${ }^{44}$ See Bird, "Dispositionalist Conception of Laws," 354.

${ }^{45}$ The symbol " $\square \rightarrow$ " denotes contrafactual implication.

${ }^{46}$ Ibid., 355.
} 
The significant conclusions to be drawn from (2) are that the necessity of this law is ontologically metaphysical and that it is epistemologically a posteriori. These two conclusions originate from the ideas of Kripke and Putnam. In their view, what causes water to be water is its essence, not the meaning and description of the word "water," which may differ depending on language or time. Moreover, the essence of water is the same in any possible world. ${ }^{47}$ Therefore, the essence of water is metaphysically necessary for something to be water. Nevertheless, this necessity is a posteriori because determining the essence of a natural kind such as water is possible only through science. According to Kripke, the essence of a natural kind will be discovered by natural scientists. ${ }^{48}$ Thus, the essence of water is $\mathrm{H}_{2} \mathrm{O}$, and this is the same in all possible worlds. Kripke's and Putnam's significant contribution to contemporary analytic metaphysics was that they showed that it is not contradictory for a proposition to be metaphysically necessary but epistemologically a posteriori. ${ }^{49}$

\section{Comparison and Analysis}

What has been explained so far about the neo-Sadraian, universalist, and essentialist approaches indicates that they are similar in some aspects while retaining fundamental differences. In this section, these three approaches are discussed under the headings of the ontology of necessity, the epistemology of necessity, and the identity of the laws of nature.

\subsection{Ontology of Necessity}

A significant difference between universalist theory and the other two perspectives (neo-Sadraian and essentialism) can be found in their approach to the ontology of necessity. Armstrong considers laws to be necessary relations between universals and regards the law itself as a second-order universal. Nevertheless, while Armstrong acknowledges the reality of universals, he interprets the universals physically. This is due to his affiliation with metaphysical naturalism; thus, he says:

\footnotetext{
${ }^{47}$ See Hilary Putnam, "The Meaning of 'Meaning," in Language, Mind, and Knowledge (Minneapolis: University of Minnesota Press, 1975), 140.

${ }^{48}$ See Saul A. Kripke, Naming and Necessity (Cambridge, MA: Harvard University Press, 1972), 137-39.

${ }^{49}$ See Putnam, "Meaning of 'Meaning."”
} 
A major reason for accepting the principle of instantiation is my desire to uphold, along with realism about universals, the logically independent doctrine of naturalism. Naturalism I define as the view that nothing else exists except the single, spatio-temporal, world, the world studied by physics, chemistry, cosmology and so on. ${ }^{50}$

Armstrong's approach to metaphysical naturalism is a reason why he rejects metaphysical necessity. According to Swinburne, necessity is too great to fit into a scientific explanation. ${ }^{51}$ For this reason, many naturalists are irrealists about modal concepts. ${ }^{52}$

It is necessary here to review the difference between Armstrong's view and Sadra's philosophy on universals. ${ }^{53}$ In Sadra's philosophy, natural universals are defined as quiddity qua quiddity. To clarify, Sadraians, following Avicenna, distinguish three types of quiddity: ${ }^{54}$

1. Conditioned by something (bi-shart shay): That is, when all accidents and individuating factors of the thing are considered, then that quiddity appears as an extra-mental existent.

2. Negatively conditioned (bi-shart la $\bar{a}$ : if the same quiddity is considered devoid of all the individuating factors and accidents, that is, with the condition that nothing can accompany it, then it exists only in the mind.

3. Unconditioned by anything ( $l \bar{a} b i$-shart $)$ : A quiddity can also be thought of as transcending all forms of conditionality.

Accordingly, in Sadra's view, natural universals belong to the third type (unconditioned by anything) and therefore cannot be realized outside the mind with the attribute of being universal, because, according to the above definition, it leads to a contradiction. On the other hand, natural universals cannot be realized as particulars because this leads to a transformation of essence, which is impossible. Finally, Sadra suggests that natural universals exist outside the mind with the condition of individuation and exist in the

\footnotetext{
${ }^{50}$ See Armstrong, What Is a Law of Nature?, 76.

${ }^{51}$ See Richard Swinburne, The Existence of God (Oxford: Oxford University Press, 2004), 74.

${ }^{52}$ See David Papineau, "Naturalism," in Stanford Encyclopedia of Philosophy, accessed February 19, 2021, https://plato.stanford.edu/archives/win2016/entries/naturalism.

${ }^{53}$ This point has been added at the suggestion of the reviewer whose explanations helped to complete this part of the paper.

${ }^{54}$ This trilogy has been properly formulated and presented by the reviewer. It is rooted in Avicenna. See Avicenna, Metaphysics of The Healing, 149-56.
} 
mind with the condition of universality. ${ }^{55}$ To clarify, Sadra believes that natural universals do not have independent external existence. Their existence depends on, and is derived from, the individual. Neo-Sadraians like Tabatabaei hold the same view. ${ }^{56}$

Consequently, Armstrong, who considers the principle of instantiation as a condition required for acceptance of the existence of natural universals, believes that natural universals are should be seen as conditioned by something (bi-shart shay, according to the works of Sadra and Avicenna). However, Sadra and his followers regard natural universals as unconditioned by anything ( $l \bar{a} b i$-shart $)$, which means their existence is dependent on independent beings.

Unlike Armstrong, metaphysical necessity is acceptable in the ontology of neo-Sadraians and essentialists. In Sadra's philosophy, necessity forms part of the general remit of philosophy, and is a property of being (mawjud) qua being, the study of which is only permissible through philosophy and not natural sciences. Neo-Sadraians argue that natural sciences have fundamental limitations in dealing with issues such as existence, necessity, and unit because of the use of empirical methods. On the other hand, the natural sciences require axioms that justify the necessity of natural regularities. Without such axioms, scientific inquiry is meaningless. ${ }^{57}$ In general, ontologically speaking, the natural sciences require philosophy and metaphysics, while, contrary to Armstrong's view, philosophy does not depend on the natural sciences to prove or disprove the existence of anything.

Although proponents of essentialism theory are not in total agreement with the broad metaphysics of the neo-Sadraians and attempt to stay in the realm of naturalism..$^{58}$ They remain realistic about metaphysical necessity ${ }^{59}$ because they are realistic about dispositional properties (which, as we know, may not yet have been actualized). Contrary to Armstrong's view, essentialists do not believe that the principle of instantiation is a prerequisite to endorsing universals or dispositional properties. By appealing to the indis-

\footnotetext{
${ }^{55}$ See Muhammad U Faruque, "Mullā Sadrā on the Problem of Natural Universals," Arabic Sciences and Philosophy 27, no. 2 (2017): 298.

${ }^{56}$ See Tabatabai, Bidayat Al-Hikmah, 57.

${ }^{57}$ See Motahari, Majmue Asar-e Ostad Motahari [The Collected Works of Motahari], vol. 6, 539.

${ }^{58}$ Birds argues "if one's naturalistic principles are formulated in terms of supervenience, then necessary entities are left untouched." See Bird, Nature's Metaphysics, 114.

${ }^{59}$ Ibid.
} 
pensability arguments ${ }^{60}$ put forward by Putnam and Quine, Bird argues in support of the realistic approach of metaphysical necessity. ${ }^{61}$

\subsection{Epistemology of Necessity}

All three of the theories I have considered hold necessity to be epistemologically a posteriori. Their differences lie in their interpretations of what it means to be a posteriori. To explain this difference, consider the following proposition (law):

"Water boils at 100 degrees Celsius."

For this example, proponents of universals theory would state that, between the universal of "being water" and the universal of "boiling at 100 degrees Celsius," there is a necessary relation. To find this relation, scientists take (actualized) water to the laboratory and study its behavior at 100 degrees Celsius. Hence, Armstrong believes in a posteriori realism about universals. ${ }^{62}$

The essentialist interpretation of this proposition, on the other hand, is that water has a dispositional property wherein the stimulus of 100 degrees Celsius necessitates the manifestation of boiling. Empirical scientists explain why water has this dispositional property by examining its essence, which is the $\mathrm{H}_{2} \mathrm{O}$ molecule. Thus, scientific inquiry on the water itself is not needed. Once we have access to the essence of water, we can explain its manifestations under different conditions.

Neo-Sadraian philosophy agrees with that of the essentialists except in so far as it considers the specific form of water to be responsible for its dispositional properties. Therefore, because the specific form is the efficient cause of a different physical form, at 100 degrees Celsius, the specific form of water causes the physical form of boiling. However, as mentioned, like the essentialists, Tabatabaei argues that science must be employed to know the specific form of water.

In short, the difference between the essentialist and the neo-Sadraian is merely verbal. Both use science to know the essence (or specific form) and, through the knowledge of essence, they explain the manifestations of natu-

\footnotetext{
${ }^{60}$ According to this principle, Quine and Putnam argue that whatever is an essential component of a physical theory (such as the law of gravity) must have actual existence, like sets and numbers. See Hilary Putnam, Philosophy of Logic (New York: Routledge, 2010), 53-56.

${ }^{61}$ See Bird, Nature's Metaphysics, 114.

${ }^{62}$ See Armstrong, What Is a Law of Nature?, 76.
} 
ral kinds. Nevertheless, the difference between these two perspectives and the theory of universals is more than a verbal difference. One who ascribes to the theory of universals does not consider the mediating element of the essence for acquiring a posteriori knowledge of the necessitation but, rather, examines the behavior of the natural kind directly.

\subsection{Identity of the Laws of Nature}

The laws of nature can be divided, from one perspective, into the descriptive and prescriptive viewpoints. Accordingly, necessitarian or deterministic theories such as that for universals are considered prescriptive, wherein the laws govern natural objects. Non-necessitarian perspectives such as regularity theory are considered to be descriptive; that is, the law merely describes the relations in nature. ${ }^{63}$ Although this categorization is arguably imperfect because essentialism is necessitarian yet it does not require a governing natural object, nevertheless, the concept of laws governing natural objects can serve as a suitable criterion for comparison of the identity of law for both the universalist and the essentialist as well as the neo-Sadraian approach.

As stated, the theory of universals is funded upon the categorical properties of natural kinds. Categorical properties are fixed and actualized properties that do not change under the influence of internal powers but, instead, change based on external, independent laws. Therefore, natural kinds are considered passive entities governed by the laws of nature. Consequently, the laws are independent of universals and objects, which are taken to be necessary based on IBE. Also, because laws do govern the relations and behaviors of natural kinds, one cannot consider the feature of natural kinds to be intrinsic and eternal. For instance, burning is not intrinsic to fire; it is only the law of the actual world that has endowed fire with this property. Fire could exist while causing coldness. This is the meaning of contingent necessity, which is characteristic of the theory of universals.

However, for the essentialists, the essence of natural kinds is determined by their dispositional properties and laws supervene upon these properties. As a result, laws do not create properties, but it is the properties that create laws. Thus, laws do not have existential priority over properties and cannot govern natural objects. Additionally, there are no laws in a world where there are no natural kinds and no dispositional properties. Likewise, as long

${ }^{63}$ Helen Beebee, "The Non-Governing Conception of Laws of Nature," Philosophy and Phenomenological Research 61, no. 3 (2000): 573. 
as the objects exist, their dispositional properties exist and, consequently, the laws exist. Therefore, in every possible world, if there is a fire, it has the property of burning.

In order to clarify the neo-Sadraian perspective, it is useful to explain the Mu'tazila ${ }^{64}$ approach to Islamic theology, which is very similar to universalist theory, and then to remark on the reflection of neo-Sadraians when facing this approach. The Mu'tazila believe in causality in nature and determinism. In this respect, they maintain some distance from the Ash 'arites. ${ }^{65}$ However, they have a particular belief regarding causality called generative action, which states that God has granted causal power to natural objects. In their opinion, natural objects do not behave according to their essence but rather due to the power and properties that God has granted them. Additionally, God can take away those properties whenever He wants. ${ }^{66}$

While both the Mu'tazila and Armstrong consider laws as something derived from a source other than natural objects, the advantage of Mu'tazilite perspective over universals theory is that the origin of the law is clear. The Mu'tazila consider God as the legislator of the law, who governs natural objects through His legislation. Contrary to this belief, the neo-Sadraian philosophers propose the idea of causal necessity, which is rooted in the ontological indigence of the contingent beings. Specifically, regarding natural objects, the neo-Sadraian philosophers consider the specific form to be the origin of the essential properties of the objects. Thus, nothing, not even divine law, necessitates essential properties and relations between the natural kinds. This is the crux of the statement by Avicenna quoted by neo-Sadraian philosophers that "God did not make the apricot an apricot - he created it." 67 According to Motahari, the difference between the apple and the apricot lies in their essence, not because God created them in these different shapes. The following table summarizes and compares these three perspectives.

\footnotetext{
${ }^{64}$ Mu'tazila is a theological party in Islam that was raised in the 8 th century.

${ }^{65}$ To secure the concept of absolute divine power, the Ash'arites rejected the actuality of natural objects and causal necessity. Al-Ghazali, as an Ash'ari argues that the relation between objects is due to the simultaneity that God has predestined between two things, which philosophers misunderstand as the cause and the effect. He gives the example of fire and the burning of cotton, and believes that a transformation can occur within cotton such that it would no longer be burnt by fire - because the cause of combustion is God, not fire. (See Al-Ghazali, 168).

${ }^{66}$ See Abu-l-Husain Abd al-Rahman Khayyat, Kitab Al-Intisar Wa-l-Radd Ala Ibn Al-Rawandi Al-Mulhid (Cairo: Maktabah al-Saqafah al-Diniah, 1988), 91.

${ }^{67}$ See Motahari, Majmue Asar-e Ostad Motahari [The Collected Works of Motahari], vol. 1, 171.
} 


\begin{tabular}{|l|l|l|l|}
\hline $\begin{array}{l}\text { Analysis of } \\
\text { perspectives }\end{array}$ & $\begin{array}{l}\text { Ontological } \\
\text { necessity }\end{array}$ & $\begin{array}{l}\text { Epistemological } \\
\text { necessity }\end{array}$ & $\begin{array}{l}\text { Identity } \\
\text { of law of nature }\end{array}$ \\
\hline $\begin{array}{l}\text { Neo- } \\
\text { Sadraian } \\
\text { between cause and } \\
\text { effect, or between } \\
\text { the specific form and } \\
\text { physical form.) }\end{array}$ & $\begin{array}{l}\text { A posteriori } \\
\text { the specific form } \\
\text { through observation } \\
\text { and science) }\end{array}$ & $\begin{array}{l}\text { The relation between } \\
\text { potentiality and } \\
\text { actuality }\end{array}$ \\
\hline $\begin{array}{l}\text { Bird's } \\
\text { essentialism }\end{array}$ & $\begin{array}{l}\text { Metaphysical } \\
\text { (dispositional } \\
\text { properties of natural } \\
\text { kinds) }\end{array}$ & $\begin{array}{l}\text { A posteriori } \\
\text { (knowledge of } \\
\text { dispositional } \\
\text { properties through } \\
\text { science) }\end{array}$ & $\begin{array}{l}\text { The relations } \\
\text { between } \\
\text { dispositional } \\
\text { properties of natural } \\
\text { kinds }\end{array}$ \\
\hline $\begin{array}{l}\text { Armstrong's } \\
\text { universals }\end{array}$ & Physical & $\begin{array}{l}\text { A posteriori } \\
\text { (knowledge } \\
\text { of actualized } \\
\text { properties) }\end{array}$ & $\begin{array}{l}\text { The relations } \\
\text { between the } \\
\text { universals and } \\
\text { unknown origin }\end{array}$ \\
\hline
\end{tabular}

Table 1. Comparison of views

\section{Conclusion}

In this article, I have explained that the approach of neo-Sadraian philosophers to necessity is similar to the essentialist perspective. This is true ontologically, with respect to their conception of considering metaphysical necessity, and epistemologically, with respect to the availability of a posteriori knowledge of necessity. This approach is inconsistent with the physical necessity countenanced in the theory of universals.

\section{Acknowledgements:}

I would like to express my special thanks of gratitude to Professor Seyyed Hassan Hosseini, who provided insight that considerably assisted the research. And I thank two anonymous reviewers for comments that improved the manuscript. The earlier version of the paper was presented at the department of philosophy of science at Sharif University. 


\section{Bibliography:}

Al-Ghazali. The Incoherence of the Philosophers. Brigham: Brigham Young University Press, 2000.

Aristotle. Physics. New Brunswick: Rutgers University Press, 1995.

Armstrong, David. "Laws of Nature As Relations Between Universals, and As Universals." Philosophical Topics 13, no. 1 (1982): 7-24.

Armstrong, David. What Is a Law of Nature? Cambridge: Cambridge University Press, 1983.

Avicenna. Kitab Al-Najat [The Book of Deliverance]. Tehran: University of Tehran, 2001.

Armstrong, David. The Metaphysics of The Healing. Brigham: Brigham Young University Press, 2005.

Beebee, Helen. "The Non-Governing Conception of Laws of Nature." Philosophy and Phenomenological Research 61, no. 3 (2000): 571-94.

Bird, Alexander. Nature's Metaphysics: Laws and Properties. Oxford: Clarendon Press, 2007.

Bird, Alexander. “The Dispositionalist Conception of Laws." Foundations of Science 10 (2005): 353-70. https://doi.org/10.1007/s10699-004-5259-9.

Ellis, Brian. The Philosophy of Nature: A Guide to the New Essentialism. Stocksfield: Acumen Publishing Limited, 2002.

Faruque, Muhammad U. "Mullā Sadrā on the Problem of Natural Universals." Arabic Sciences and Philosophy 27, no. 2 (2017): 269-302.

Feser, Edward. "From Aristotle to John Searle and Back Again: Formal Causes, Teleology, and Computation in Nature." Nova et Vetera 14, no. 2 (2016): 459-94. https://doi.org/10.1353/nov.2016.0039.

Fraassen, Bas C van. Laws and Symmetry. Oxford: Oxford University Press, 1989. https://doi.org/10.1093/0198248601.001.0001.

Ha'eri yazdi, Mehdi. Heram e Hasti [Pyramid of the Universe]. Tehran: Institute of Cultural Studies and Research, 1982.

Ha'eri yazdi, Mehdi. Sharh-i Harakat-i Asfār [Explanation of Motin in Asfar]. Tehran: Hekmat, 2015. 
Hume, David. A Treatise of Human Nature. Waiheke Island: The Floating Press, 2009.

Kalin, Ibrahim. Knowledge in Later Islamic Philosophy: Mulla Sadra on Existence, Intellect, and Intuition. Oxford: Oxford University Press, 2010.

Khayyat, Abu-l-Husain Abd al-Rahman. Kitab Al-Intisar Wa-l-Radd Ala Ibn Al-Rawandi Al-Mulhid. Cairo: Maktabah al-Saqafah al-Diniah, 1988.

Kim, Jaegwon. “The American Origins of Philosophical Naturalism.” Journal of Philosophical Research 28 (2003): 83-98.

https://doi.org/10.5840/jpr200328supplement28.

Kripke, Saul A. Naming and Necessity. Cambridge, MA: Harvard University Press, 1972.

Lewis, David. "New Work for a Theory of Universals.” Australasian Journal of Philosophy 61, no. 4 (1983): 343-77. https://doi.org/10.1080/00048408312341131.

Loux, Michael J., and Thomas M. Crisp. Metaphysics: A Contemporary

Introduction. Teaching Philosophy. New York: Routledge, 2017.

https://doi.org/10.5840/teachphil201740374.

Motahari, Morteza. Majmue Asar-e Ostad Motahari [The Collected Works of Motahari]. Vol. 1. Tehran: Sadra, 2005.

Motahari, Morteza. Majmue Asar-e Ostad Motahari [The Collected Works of Motahari]. Vol. 6. Tehran: Sadra, 2005.

Motahari, Morteza. Majmue Asar-e Ostad Motahari [The Collected Works of Motahari]. Vol. 10. Tehran: Sadra, 2005.

Papineau, David. "Naturalism." In Stanford Encyclopedia of Philosophy. Stanford University, 1997-. Article published September 15, 2015.

https://plato.stanford.edu/archives/win2016/entries/naturalism.

Putnam, Hilary. Philosophy of Logic. New York: Routledge, 2010.

Putnam, Hilary. “The Meaning of 'Meaning." In Language, Mind, and Knowledge, edited by Keith Gunderson, 131-93. Minneapolis: University of Minnesota Press, 1975.

Sadr al-Din al-Shirazi, Mohammad Ibn Ibrahim. Al-Hikma Al-Muta'aliya Fi-lAsfar Al-'aqliyya Al-Arba'a. Vol. 2. Beirut: Dar ehya al-torath al-arabi, 1981.

Sadr al-Din al-Shirazi, Mohammad Ibn Ibrahim. Al-Hikma Al-Muta'aliya Fi-lAsfar Al-'aqliyya Al-Arba'a. Vol. 3. Beirut: Dar ehya al-torath al-arabi, 1981. 
Swartz, Norman. "Laws of Nature," In Internet Encyclopedia of Philosophy. Article published 1995. http://www.iep.utm.edu/lawofnat.

Swinburne, Richard. The Existence of God. Oxford: Oxford University Press, 2004.

Tabatabai, Sayyed Muhammad Husayn. Bidayat Al-Hikmah. Qom: Muassasah al-Nashr al-Islamiyah, 1995.

Swartz, Norman. Nihayat Al-Hikmah. Qom: Muassasah al-Nashr al-Islamiyah, 1984.

Tooley, Michael. "The Nature of Laws." Canadian Journal of Philosophy 7, no. 4 (1977): 667-98. https://doi.org/10.1080/00455091.1977.10716190. 